\title{
Public-Private Partnership in the Implementation of the Industrial Policy of Russia
}

\author{
A.D. Kasatov ${ }^{1, *}$ \\ *Corresponding author: kasatov47@mail.ru. \\ ${ }^{1}$ Samara State University of Economics, Samara, Russia
}

\begin{abstract}
The article views the creation of public-private partnership as an important direction in the activation of the innovative type of the development of the economy of Russia. The need to combine the efforts of the public and private business in solving this problem is connected, firstly, with the economic sanctions of the West and not only financial sanctions but also with the refusal to supply high-tech equipment to Russia and, secondly, even more threatening prospects of the dynamics of the innovative development of the manufacturing sector. That is why the main attention is paid to the impact of public-private partnership on the development of integrated business in the context of the implementation of the strategic task of the innovative way of the Russian economy development. It is shown that public-private partnerships are one of the most common instruments for attracting private investments in infrastructure projects both in Russia and abroad. But the format of public-private partnerships for the implementation of Russia's industrial policy in the field of innovation should be used not only for the infrastructure development but also for the development of Russian industrial enterprises and the implementation of national projects.
\end{abstract}

Keywords: public-private partnership, industrial policy, innovative development way, national projects.

\section{Introduction}

In modern conditions the relevant problem is the implementation of the Federal Law of the Russian Federation "On Industrial Policy in the Russian Federation" and, above all, in the formation of a high-tech, competitive industry that ensures the transition of the state economy from the export-raw materials type of development to the innovative type of development [1]. This is due to the preservation of a critical degree of moral and physical depreciation of fixed assets of the industry of the Russian Federation. During the period of market reforms, the creation of an organizational and economic mechanism of providing stable reproduction of fixed assets of such quality which is necessary for the production of competitive industrial products. On the background of the preservation of a significant share of uncompetitive fixed assets, there is a hypertrophied increase in financial investments in various types of commercial transactions that are not directly related to solving of the key investment problems of the innovative development of industry.

Overcoming of the technical and technological weakness of the industrial enterprises, bringing them into line with Western analogues is associated with the increase in production efficiency, product quality and competitiveness. In this regard, the main task is to attract investments in the innovative development of the industrial companies. According to the Federal State Statistics Service, the share of Russian organizations engaged in technological innovation decreased from $7.9 \%$ in 2010 to $7.5 \%$ in 2017, and the proportion of innovative goods, work, services in the total volume of the shipped goods, work performed and services amounted to: $10.4 \%$ in $2000,4.8 \%$ in $2010,8.4 \%$ in $2015,8.5 \%$ in 2016 and $7.2 \%$ in 2017 [2].

In the innovative respect, the development of industries is seriously aggravated, firstly, by the economic sanctions of the West, and not only financial sanctions but also by the refusal to supply high-tech equipment to Russia; secondly, the dynamics of the innovative development of the manufacturing sector is even more threatening in the future. Both of these positions in their unity once again lead to the need for active interaction between the state and the private business.

That is why the creation of IBS on the basis of public-private partnership is an urgent problem for the modern Russian economy. Due to their financial, economic and production potential, IBS is the most appropriate form of public-private partnership, which allows implementing of investment projects of national importance. The formation of IBS with a mixed form of ownership makes it possible, on the one hand, to ensure the priority of state interests and, on the other hand, to attract private investments on the basis of private investors' participation in the capital of IBS. The most common form of public-private partnership is a holding-type corporation.

\section{Methods}

Methods of strategic and innovative analysis, methods and means of economic, statistical and logical analysis were used in the research. The information base was compiled by the data of Rosstat (Federal Service of State Statistics), the materials from financial and economic publications of Russia, the Internet, publications from periodicals, scientific publications of domestic and foreign researchers, presented in the form of articles, monographs and theses as well as the materials of international scientific conferences. 


\section{Results}

In solving of the burning problems of ensuring of the investment growth of fixed capital and the increasing of the industrial competitiveness, an important role is played by the large domestic business. In integrated business structures such as public-private partnerships there are created objective preconditions for the concentration of financial resources for the solving of priority investment problems associated with the modernization of the economy on an innovative basis. The main directions of the modern trends in the development of domestic integrated business in Russia, which should include integrated industrial groups, strategic alliances, clusters, etc., are widely covered in the economic literature [3, 4].

In the Russian economy, state activity is noticeable at the level of strategic integration processes, especially in the most important types of the economic activity. State bodies either act as the organizers of the integration, or do not impede the inclusion of enterprises with state participation in the share capital formed at the initiative of joint-stock companies in the corporate structures [5].

Throughout the world the trend of implementing of partnership projects between the state and business is gaining strength. The basis of public-private partnership (PPP) is the concept that achieving more favorable price / quality ratio of services that have traditionally been presented by the public sector is connected with the ability to use the private sector managerial potential (including qualifications, management and finance), as well as the distribution of the project risks among the participants.

With the adoption of the Federal Law "On Public-Private Partnerships, Municipal-Private Partnerships in the Russian Federation and Amendment of Certain Legislative Acts of the Russian Federation" [6] this interaction received a legal basis, the purpose of which is to attract private investments in the Russian economy and to improve the quality of goods and services, the provision of which to the customer is managed by the government bodies and local authorities.

Public-private partnership is one of the most common instruments for attracting private investments in infrastructure projects. Taking into consideration the social significance of the state of infrastructure, most countries create and modernize infrastructure facilities on the account of budgetary allocations. First of all, the state finances the construction of roads, the creation of public utilities, the modernization of social infrastructure, the development of education and health care, etc. Moreover, as practice shows, government resources alone are not enough to satisfy the demand for infrastructure investments in full [7].

Most countries of the world, regardless of the level of development of their economies, are trying to implement infrastructure projects with the involvement of extra-budgetary funds and private investors, which significantly reduces the burden on the budget and improves the quality and efficiency of infrastructure facilities maintenance. At the same time, the feasibility of implementation of an infrastructure project in the PPP format is evaluated in relation to each specific case. Public-private partnership cannot solve all the problems of infrastructure development in the country but PPP mechanisms in some cases can significantly increase the efficiency of public spending and it is especially important in conditions of state budget deficit. In this regard, the interaction of the state and private business in the implementation of national projects not only in the social but also in the industrial sphere is essential. So far this interaction is limited.

Thus, for the implementation of the industrial policy in the field of the innovative development of Russian industrial enterprises and the implementation of national projects, the format of public-private partnership is a promising area of interaction between the state and private business. For state institutions, PPP is a tool which helps to make industrial policy more perceptive to the changing nature of innovations, as well as social and sanction constraints. For private business PPP will be helpful in developing new markets and making business more valuable.

\section{Conclusion}

The content of the research carried out in the article does not pretend to be an exhaustive disclosure of all theoretical and practical problems of the Russian industrial policy aimed at the development of public-private partnerships in the implementation of innovative investment projects not only in the social but also in the industrial sphere. The author thinks it is necessary to make more profound study of these problems in both fundamental and applied areas.

\section{Acknowledgements}

The study was carried out with the financial support of the Russian Federal Fund of Fundamental Research within the framework of the scientific project No. 18-010-00359 "Theoretical and Practical Problems of the Industrial Policy of the Development of Public-Private and Municipal-Private Partnerships in the Innovation Environment." 


\section{References}

1. The Federal Law of 31.10. 2014 № 488-FZ «About Industrial Policy in the Russian Federation» (2014).URL: http://www.consultant.ru/document/cons doc LAW 173119/. Accessed: 09.09.2019. [in Rus.].

2. Rosstat, Russian statistical yearbook (2018). URL: https://www.gks.ru/storage/mediabank/year18.pdf. Accessed: 09.09.2019.

3. Yu.V. Yakutin. Integrated corporate structures in the market economy of Russia (Free Economic Society of Russia, Moscow, 2009). [in Rus.].

4. Yu. B. Vinslav, Integrated business management: Theoretical and methodical aspects. Management innovations for large business (Publishing House «Centre-LitNefteGas», Moscow, 2017). [in Rus.].

5. S.B. Avdasheva, T.G. Dolgopyatova, H. Plyaynes, Corporate management in JSC with state participation: Russian problems in the context of the world experience (Publishing House of the State University High School of Economics, Moscow, 2007). [in Rus.].

6. The Federal Law of 13.07.2015 № 224-FZ «About Public-Private Partnership, Municipal-Private Partnership in the Russian Federation and Making Amendments in some Legislative Acts of the Russian Federation» (2015). URL: http://www.consultant.ru/document/cons doc LAW 182660/. Accessed: 09.09.2019.

7. V.N. Mochalnikov, Public-private partnership: Domestic experience, world tendencies, the development vector for Russia (Economics, Moscow, 2011). [in Rus.]. 